Philosophical Letters. Russian and European Dialogue. 2021. Vol. 4, no. 3. P. 233-241. Философические письма. Русско-европейский диалог. 2021. Т. 4, № 3. С. 233-241.

Book Review / Рецензия на книгу

УдК 1(091)

doi:10.17323/2658-5413-2021-4-3-233-241

\title{
THE CORRESPONDENCE BETWEEN SEMEN FRANK AND LUDWIG BINSWANGER (1934-1950)
}

The Correspondence Between Semen Frank and Ludwig Binswanger (1934-1950). Edited by K. M. Antonov, G. E. Aliaev, F. Bubbaier et al. Moscow: St. Tikhon Orthodox Theological University for the Humanities Press, 2021. 960 p. (In Russ.)

Kåre J. Mjør

The Western Norway University of Applied Sciences, Bergen, Norway, kare.johan.mjor@hvl.no

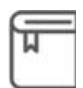

For citation: Mjør, K.J. (2021) 'The Correspondence Between Semen Frank and Ludwig Binswanger (1934-1950)', Philosophical Letters. Russian and European Dialogue, 4(3), pp. 233-241. (In Russ.). doi:10.17323/2658-5413-2021-4-3-233-241.

Научная жизнь. Рецензии. Обзоры

ПЕРЕПИСКА С. Л. ФРАНКА И Л. БИНСВАНГЕРА (1934-1950)

Переписка С. Л. Франка и Л. Бинсвангера (1934-1950) / ред. кол.: К. М. Антонов (отв. ред.), Г. Е. Аляев, Ф. Буббайер и др. - М.: Изд-во ПСТГУ, 2021. — 960 с.

Коре Йохан Мьёр Университет прикладных наук Западной Норвегии, Берген, Норвегия, kare.johan.mjor@hvl.no

(C) Mjør, K. J., 2021 
Ссылка для цитирования: Мьёр К. Й. Переписка С. Л. Франка и Л. Бинсвангера (1934-1950) // Философические письма. Русско-европейский диалог. 2021. T. 4, № 3. C. 233-241. https://doi.org/10.17323/2658-5413-2021-4-3-233-241.

cholarship on the Russian philosopher Semon Frank is currently experiencing a significant growth. In addition to new interpretations of and commentaries to his philosophical works, a number of publications recently has contributed to his biography by documenting various stages of his life in exile. ${ }^{1}$ A new edition of his complete works is also on it way, published by the St. Tikhon Orthodox Theological University for the Humanities Press; at the time of writing three volumes have appeared [Frank, 2018-].

Scholars involved in the projects referred to above are also among the editors of the book under review here, an impressive, 960 pages long volume that provides the correspondence between Frank and the Swiss "existential psychologist” Ludwig Binswanger, which took place in the years 1934-1950, that this until the final year of Frank's life. Its editors are Konstantin Antonov, Gennadyi Aliaev, Philip Boobbyer, Aleksei Gaponenkov, Tatiana Rezvykh, Aleksandr Tsygankov, Daria Chentsova and Vladimir Janzen. The book includes a 60 pages long introduction, the full surviving correspondence between Frank and Binswanger, and also correspondence between Binswanger and other members of Frank's family after Frank passed away in 1950. The book is bilingual: the letters, which were originally for the most part written in German (with a few cases of French and English), are published in both original and in a Russian translation. Responsible for the translation has been Aleksandr Tsygankov and Vladimir Janzen. The correspondence has come down to us via Tübingen University Library, and a selection of it was previously published by the British Frank scholar Phillip Boobbyer in a series of issues of Forum für osteuropäische Ideen- und Zeitgeschichte (2013-2015), while the book under review here provides the correspondence in full.

The correspondence is interesting for both Frank scholars and scholars of Russian philosophy and thought more generally for reasons that will be explained below. However, let it be noted that it should also be of interest to those who study Binswanger's legacy and most generally idealist and existentialist thought of mid-war Europe, and the conversation and common ground of Frank and Binswanger suggest that "Europe" should be conceived in a broader sense than Western scholars normally do. In

${ }^{1}$ Examples wof recent research include (Aliaev, 2020; Aliaev, Obolevitch, Rezvykh, 2021; Obolevitch, 2020; Tsygankov, Obolevitch, 2019; Tsygankov, Obolevitch, 2020). 


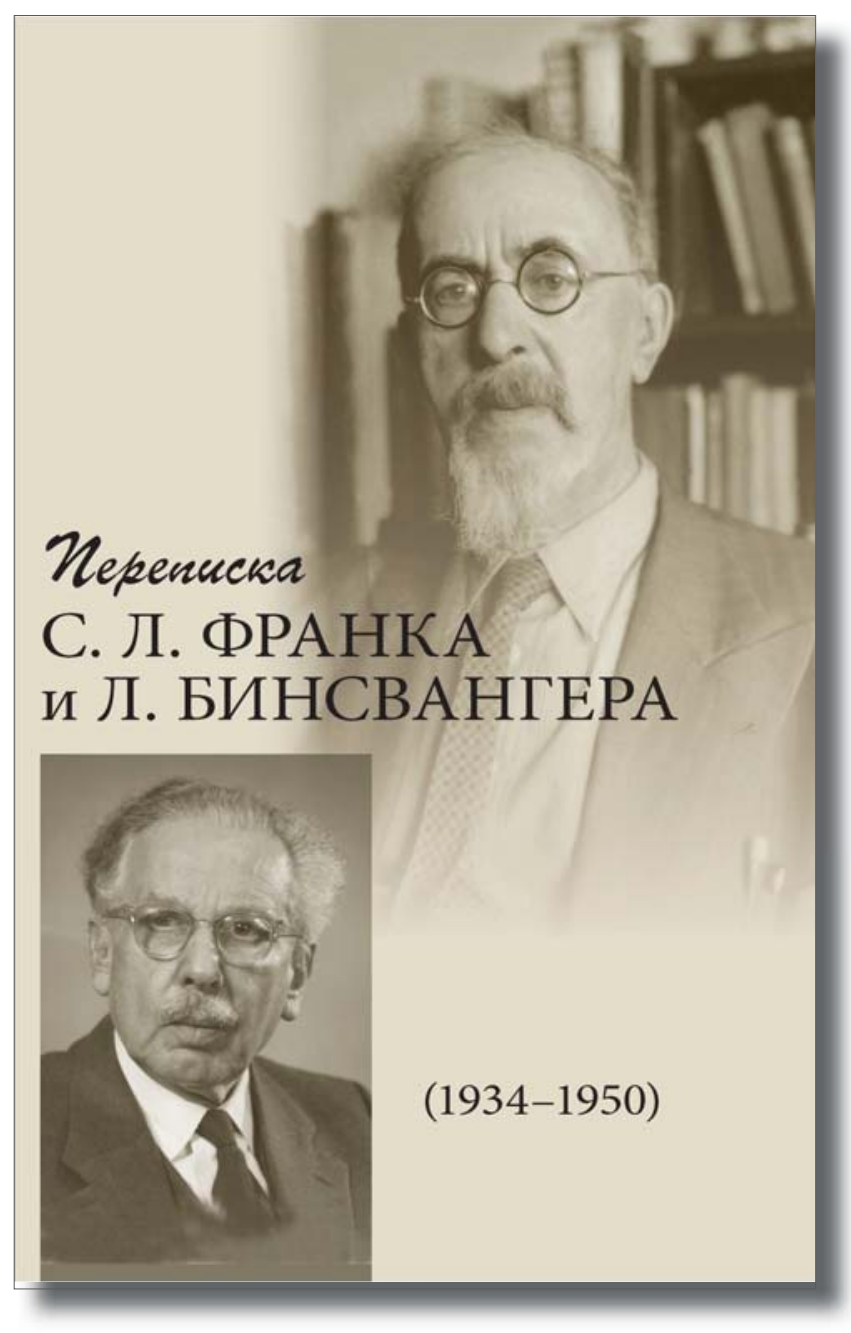

any case, the exchange of philosophical ideas between the Russian philosopher and Swiss psychiatrists offers a fascinating example of what the editors describe as a dialogue between two traditions, the Russian and West-European. Moreover, the published letters offer a glimpse into Frank's life in exile, and more generally the difficult life of Russian emigres in interwar Europe under harsh economic conditions. Apart from the condition of exile itself, Frank, residing in Germany in the 1930s, experienced additional difficulties there due to his Jewish background.

The editors' introduction offers a commentary on all these dimensions. It reconstructs the altogether six encounters between the two figures, which, evidently, is based not only on their correspondence but also other sources. For instance, Binswanger wrote his "Recollections about Semen Ludvigovich Frank" for a volume to the memory of Frank edited by Vasilii Zenkovskii and published in 1954. After a biographical account, the introduction proceeds to a thorough and illuminating discussion of philosophical topics and thinkers to which their discussions were devoted: Freud and in particular Heidegger.

Semen Frank was a prominent representative of the neo-idealist turn in Russian philosophy, beginning with Vladimir Solov'ev and continuing with the generation to which Frank belonged, which included Sergei Bulgakov, Nikolai Berdiaev and others. They spelled out their arguments in the collections Problems of Idealism (1902) and Signposts (1909), and Frank published two of his philosophical major works in the 1910s while still living in Russia: The Object of Knowledge (1915) and The Soul of Man (1917). In a characteristic neo-idealist vein, Frank combined epistemology and ontology, using the former to draw ontological conclusions about the absolute. Later on, Frank emerged as one of the passengers on the "philosophical steamship," that is one of several idealist and religious philosophers who were expelled by the new Soviet regime in 1922. Frank settled first in Berlin. As the editors explain, life in exile was 
difficult for Frank in several respects, not just financially and materially. It was difficult for Frank also to pursue his philosophical projects in the 1920s. He spent a great deal of time on émigré charity work aimed at preparing the youth for its return to a liberated Russia. Moreover, his new, German audience recurrently requested from him keys to understanding Russia and Russianness, which resulted in a small but well-known book, Die russische Weltanschauung (1926). He taught at the university of Berlin, but again he was assigned Russian Geistesgeschichte and Russian literature within the Slavonic department rather than philosophy, whereas the latter after all was his main field. Although he managed to publish The Spiritual Foundations of Society in 1930, he was often understood to be a Russianist. Frank himself, meanwhile, attempted to become a "German philosopher," and he wrote the manuscript of his book Das Unergründliche (The Unknowable) in German. It was while he was working on this book, in 1934, that Frank became acquainted with Binswanger, and Frank dedicated the German edition of 1937 to Binswanger. Their first meeting took place at a philosophical conference in Amsterdam, in the Fall of 1934, where Binswanger had been invited to read a paper on Heraclitus' conception of the human being, whereas Frank a few days earlier had talked about "The Antinomy between Freedom and Equality.” Later followed five more encounters: in Binswanger's hometown Kreutzlingen (1935, 1936, 1937-1938); Paris (1939) and London (1946). Frank immediately understood himself and his colleague to be on equal terms with regard to philosophy. Their friendship and correspondence took place in the period when Frank was working on the books that became his last ones. In addition to The Unknowable, these were God with Us, The Light Shineth in Darkness and Reality and Man, and the epistolary discussions reflects the themes that preoccupied Frank in this period.

As noted, this time of Frank and Binswanger's friendship was from its very beginning difficult for Frank, due to the lack of sufficient income (Binswanger supported him financially over a longer period of time) as well as to increasing tensions and hostility in the society surrounding him. After the national socialists came to power in Germany he lost the right to teach at the Slavonic institute at the Berlin university due to his Jewish decent, and in 1937 he emigrated further, to Paris, via Switzerland and Binswanger's home in Kreutzlingen (where he stayed for a month, from December 1937 to January 1938). During the Second World War he resided first on the Riviera and then, after the fall of the Vichy regime, near Grenoble, before leaving for London towards the end of war. The correspondence with Binswanger continued as Frank moved on, and they met, as noted, one final time in London. The war communication tells us a great deal about life for a Russian émigré during wartime. In London, his activity and health were gradually decreasing, as can also be seen from the letters they exchanged. 
The extensiveness of the correspondence owes to both personal friendship and the stimulation that it exercised on the intellectual development of them both. The editors describe the collections as an "epistolary creative laboratory by two thinkers" (p. 26). As noted, Frank was at the time when the exchange began working on The Unknowable, and what resonated with him in Binswanger's thought was, according to the editors, the letter's "quest for the deep, philosophical-ontological foundations for an anthropological study" (p. 27), even from the point of view of a psychiatrist. It was in particular the revisions of The Unknowable that Frank began in 1937, revisions of a work Frank himself would consider his most significant one, that bear the influence of the conversations with Binswanger. Key in this respect was the foundational importance of the I-Thou relationship as "revealed reality" (Letter 66). As can be seen from the correspondence, Binswanger accepted the use of "revelation" in a phenomenological-ontological and not religious sense, and while he noted that the two differed when it came to the religious understanding on this term, the conversation shows that Frank too used religious concepts in a way that communicated with philosophical and more secularist approaches, and in this regard he was in line with a major tendency in Russian neo-idealism, and post-Schellingian idealism more generally. For many thinkers of the so-called Russian religious renaissance, "religiosity" refers to the experience of the unconditioned, the absolute, or "the unknowable," as opposed to the discursive or conceptual understanding, which presupposes the former. In his memoirs Binswanger noted that Frank's combination of "Christian contemplation" and "sound and clear reasoning” was "genuinely Russian” (p. 30). Frank, in another letter to Binswanger, pointed out that although he himself was "closer to Christian faith than you are" (note that he does characterize himself straightforward as a believer), it is you who has taught me "what love is," that is in a philosophical sense (Letter 206). Frank suggested moreover that Binswanger had become a teacher for him in a theological sense without really being a theologian. This resonates with what Frank wrote in God with Us - that the search for truth as well as particular ways of behavior may represent "unconscious belief" and "unconscious Christianity" (see Boobbyer, 2020, p. 506). Although the editors point out that the difference between Frank's religiosity and Binswanger's apparently more secular approach to the absolute is significant (p. 33), the exchange raises the question as to what "religiosity" really means, and where the boundary between the religious and the secular lies. This resonates with the issue that had for a while been central to several Russian neo-idealists; their preference for an "immanent" understanding of religion to a "transcendent." As the editors comment on Frank's God with Us, the explicitly religious character of his work apparently did not represent a hindrance to its reception among more secular-inclined readers such as Binswanger (p. 34). 
The correspondence also gives insight into projects that Frank pursued but never completed, such as a "philosophy of creativity," a theme clearly resonating with the ideas of Bulgakov and Berdiaev (and Schelling), but which Frank approached also linguistically. According to his letters to Binswanger, he read thoroughly up on recent studies of language and even natural sciences in order to discuss the topic of "Creation and Expression." Some aspects of these efforts can be found in his last work, Reality and Man, but all in all the philosophy of creativity, its subsection "philosophy of the word," and the overall "philosophy of philosophy" to which it was meant to contribute, were all left unfulfilled (p. 37).

The correspondence offers new conceptualizations from Frank as to how his project should be understood, for instance as the "combination of Platonic dualism with panentheistic motifs." The perspective of "panentheism" is often attributed to Frank, and as he explains it himself, it means that the this-worldly represents a revelation of that which lies beyond (Letter 184). It is also interesting to read Frank's repeated insistence on the lack of systematicity in his work, knowing that "system" was what Zenkovskii so extensively praised him for in his history of Russian philosophy, something that for Zenkovskii made Frank, together with Solov'ev, the culmination of the historical development of Russian philosophy (see Mjør, 2011, pp. 289-290).

Quite naturally, the correspondence sheds light not only on Frank's intellectual evolvement but on Binswanger's as well. The editors argue that Binswanger was under Frank's decisive influence but that this has been insufficiently recognized by those who have studied the psychiatrist's ideas. Frank has in this respect been significantly overshadowed by Heidegger. While the impact of Heidegger on Binswanger is obvious, Binswanger's own references to Frank (that is to translations of his work into German and French) should have made scholars more attentive to Frank's influence as well, and the correspondence makes this all quite clear. In Frank Binswanger found ideas similar to those of Heidegger (concerning the I-Thou relationship as prior to self-recognition), and he would later in his recollections on Frank point out that Frank overcame the many of the antinomies that go back to Descartes before Heidegger did.

In a wider perspective, this raises the question to what extent we should understand "Russian philosophy" as a separate tradition or whether it is more pertinent to view it as part of the post-idealist (that is post-Schellingian) field of European philosophy, to which Russian thinkers from Solov'ev onwards made contributions of equal significance to those of for instance Heidegger or Paul Tillich, and, noteworthy, often before the German thinkers did. The correspondence of Frank and Binswanger provides a useful source for debating these questions further. In addition to "dialogue," therefore, it seems to me equally appropriate to describe the exchange between the 
Russian and German thinkers as "symphonic philosophizing," which was Frank's own description of their epistolary conversations (Letter 93, see also Gaponenkov, Tsygankov, 2019). In a symphony different voices "sing" variations on common themes.

Another field that this publication suggests that Frank should be seen as part of is the tradition of dialogical thinking of the early twentieth century, as represented by for instance Martin Buber, Hermann Cohen, Karl Löwith and Gabriel Marcel, which in retrospect makes up an alternative philosophy of modernity (Schrey, 1970). The editors argue that Binswanger follows not Heidegger but Buber and Frank in viewing Dasein as Zweisamkeit and not Einsamkeit. The other is no "thing" or "object," but that with whom we engage and collaborate, as well as for whom we care (p. 46). Binswanger conceptualized this as "Wirheit or love" (p. 47). As for Heidegger, the correspondence shows that Frank developed a critical attitude to Heidegger, his terminology (which he discouraged from Binswanger from using) as well as his conclusions, in particular the foundational role Heidegger attributed to Angst (Letter 243). Binswanger on his part, the editors claim, remained closer to Heidegger, but nevertheless received significant impact from Frank in developing an understanding of "love as a fundamental phenomenon of human being” (p. 53). Frank meanwhile towards the very end of his life welcomed the turn that Heidegger demonstrated in his collection Holzwege, at least with regard to its criticism of predominant tendencies of the European tradition (Letter 419).

These are just some examples of the topics encountered in this correspondence. They stretch from everyday-life descriptions to thorough philosophical discussions. Frank writes also about the experience of exile and reflects on his "Russian audiences," be it the current émigré community or the "reborn Russia” of the future. As the correspondence shows, Frank continued to believe in a return to his homeland and its people there as late as in 1939, that is at a time when several of his fellow émigrés had lost this belief (Letter 114, 132). These topics make the collection a relevant and fascinating source also for historians of "Russia abroad," as it does for the historian of Russian-European philosophy and intellectual history, and due credit should be given to its editors for making it accessible to readers worldwide.

\section{References}

Aliaev, G.E. (2020) Russkaia filosofiia vokrug S.L. Franka: Izbrannye stat’i [Russian Philosophy Around S.L. Frank. Selected Articles]. Moscow: Modest Kolerov Publ. (Issledovaniia po istorii russkoi mysli. Tom. 23 [Studies in the History of Russian Thought. Vol. 23]).

Aliaev, G.E., Obolevitch, T., Rezvykh, T.N. (2021) "Svet vo t'me" $i$ "S nami Bog": Neizvestnye knigi S.L. Franka ["Light in the Dark" and "God with Us": Unknown Books 
by S.L. Frank]. Moscow: Modest Kolerov Publ. (Issledovaniia po istoriii russkoi mysli. Tom 29 [Studies in the History of Russian Thought. Vol. 29]).

Boobbyer, P. (2020) 'Semyon Frank', in Emerson, C., Pattison, G., Poole, R.A. (eds) The Oxford Handbook of Russian Religious Thought. Oxford: Oxford University Press, pp. 495-509.

Frank, S.L. (2018-) Polnoe sobranie sochinenii [Complete Works]. Moscow: St. Tikhon Orthodox Theological University for the Humanities Press.

Gaponenkov, A.A, Tsykankov, A.S. (2019) "Simfonicheskoe filosofstvovanie' (biograficheskie realii perepiski S.L. Franka i L. Binsvangera' ["Symphonic Philosophizing' (Biographical Realities of the Correspondence Between S.L. Frank and L. Binswanger)'], Vestnik PSTGU, Seriia 1: Bogoslovie, filosofia, religovedenie, 85, pp. 88-107.

Mjør, K.J. (2011) Reformulating Russian: The Cultural and Intellectual Historiography of Russian First-Wave Émigré Writers. Leiden \& Boston: Brill.

Obolevitch, T. (2020) Semen Frank, Lev Karsavin i evraziitsy [Semyon Frank, Lev Karsavin and the Eurasians]. Moscow: Modest Kolerov Publ. (Issledovaniia po istorii russkoi mysli. Tom 24 [Studies in the History of Russian Thought. Vol. 24]).

Schrey, Heinz Horst (1970) Dialogisches Denken. Darmstadt: Wissenschaftliches Buchgesellschaft.

Tsygankov, A.S., Obolevitch, T. (2019) Nemetskii period filosofskoi biografii S.L. Franka (novye materialy) [German Period of S.L. Frank's Philosophical Biography (New Materials)]. Moscow: IF RAN.

Tsygankov, A.S., Obolevitch, T. (2020) Gollandskii epizod v filosofskoi biografii S.L. Franka (novye materialy) [Dutch Episode in the Philosophical Biography of S.L. Frank (New Materials)]. Moscow: IF RAN.

\section{Список источников}

Аляев Г. Е. Русская философия вокруг С. Л. Франка. Избранные статьи. М.: Модест Колеров, 2020. 736 с. (Исследования по истории русской мысли. Т. 23).

Аляев Г. Е., Оболевич Т., Резвых Т. Н. «Свет во тьме» и «С нами Бог»: неизвестные книги С. Л. Франка. М.: Модест Колеров, 2021. 528 с. (Исследования по истории русской мысли. Т. 29).

Гапоненков А. А., Цыганков А. С. «Симфоническое философствование» (биографические реалии переписки С. Л. Франка и Л. Бинсвангера) // Вестник ПСТГУ. Сер. 1: Богословие, философия, религиоведение. 2019. Вып. 85. С. 88-107.

Оболевич Тереза. Семен Франк, Лев Карсавин и евразийцы. М.: Модест Колеров, 2020. 304 с. (Исследования по истории русской мысли. Т. 24).

Франк С. Л. Полное собрание сочинений. М.: ПСТГУ, 2018-. 
Цыганков А. С., Оболевич Т. Голландский эпизод в философской биографии С. Л. Франка (новые материалы). М.: ИФ РАН, 2020. 336 с.

Цыганков А. С., Оболевич T. Немецкий период философской биографии С. Л. Франка (новые материалы). М.: ИФ РАН, 2019. 272 с.

Boobbyer P. Semyon Frank // The Oxford Handbook of Russian Religious Thought / ed. by C. Emerson, G. Pattison, R. A. Poole. Oxford: Oxford University Press, 2020. P. 495-509.

Mjør K. J. Reformulating Russian: The Cultural and Intellectual Historiography of Russian First-Wave Émigré Writers. Leiden \& Boston: Brill, 2011. XII, 327 p.

Schrey Heinz Horst. Dialogisches Denken. Darmstadt: Wissenschaftliches Buchgesellschaft, 1970.

Information about the author: K. J. Mjør - PhD, Associate Professor of Russian at the University of Bergen, Senior Research Librarian at the Western Norway University of Applied Sciences. Address: Box 7030, 5020 Bergen, Norway.

Информация об авторе: К. Й. Мьёр — PhD, ассоциированный профессор русского языка Бергенского университета, старший научный сотрудник Библиотеки Западно-Норвежского университета прикладных наук. Адрес: Вох 7030, 5020 Берген, Норвегия.

The author declares no conflicts of interests. Автор заявляет об отсутствии конфликта интересов.

Статья поступила в редакцию 11.08.2021;

одобрена после рецензирования 27.08.2021;

принята к публикации 01.09.2021.
The article was submitted 11.08.2021; approved after reviewing 27.08.2021; accepted for publication 01.09.2021. 